\title{
Dois Novos Sistemas de Diagnose Precoce da Meleira do Mamoeiro
}

\author{
Eder T. Tavares ${ }^{1 *}$, Joseli S. Tatagiba ${ }^{2}$, José A. Ventura² ${ }^{2}$ Manoel T. Souza Jr. ${ }^{1}$ \\ ${ }^{1}$ Embrapa Recursos Genéticos e Biotecnologia, CEP 70770-900, Brasília, DF, \\ e-mail: msouza@cenargen.embrapa.br; ${ }^{2}$ INCAPER, CEP 29900-970, Linhares, ES
}

(Aceito para publicação em 07/05/2004)

Autor para correspondência: Manoel Teixeira Souza Júnior

TAVARES, E.T., TATAGIBA, J.S., VENTURA, J.A. \& SOUZA JR., M.T. Dois novos sistemas de diagnose precoce da meleira do mamoeiro. Fitopatologia Brasileira 29:563-566. 2004.

\section{RESUMO}

A diagnose da meleira do mamoeiro (Carica papaya)tem sido feita mediante observação de sintomas que aparecem principalmente nos frutos ou pela detecção de dsRNA de cerca de $12 \mathrm{~kb}$, purificado a partir do látex em coluna de CF11, em gel de agarose ou poliacrilamida. Os sintomas nos frutos são tardios e permitem longa permanência de plantas infectadas no campo e o processo usado para detectar dsRNA é laborioso, não se prestando a detecção em larga escala. Visando disponibilizar protocolos de diagnose precoce da meleira que possam ser usados em larga escala, o presente trabalho apresenta dois métodos de detecção relativamente baratos, rápidos e que permitem o manuseio de dezenas de amostras por dia. Os dois métodos utilizam o látex extraído dos frutos, folhas ou caule de plantas, e se baseiam na extração e visualização de ácidos nucléicos. A presença do vírus é confirmada pela visualização do seu dsRNA em gel de agarose (1\%) em 1X TBE. Com esta técnica temos conseguido resultados confiáveis a ponto de diagnosticar precocemente a meleira em plantas ainda jovens e em plantas assintomáticas.

Palavras-chave adicionais: Carica papaya, dsRNA, vírus.

\section{ABSTRACT}

Two new systems of early diagnosis of papaya sticky disease Papaya sticky disease was first reported affecting papaya (Carica papaya) in Brazil in the late 80s. Today this disease is found in the papaya production areas throughout Brazil, and in some of them it became the main limiting factor for the papaya industry. The primary disease symptom is an excessive exudation of highly fluid latex that becomes dark as result of oxidation and turns the fruit unmarketable. It is caused by a new virus that has an isometric particle (40-50 nm in diameter), and a unique $12 \mathrm{~kb}$ long dsRNA molecule. Since its diagnosis is done mainly by observation of the symptoms on the fruit, infected plants may be source of inoculum for several months before diagnosis. Another form of diagnosis is the detection of dsRNA from leaves and latex using CF11 columns. This is a laborious system not suited to large scale usage. The present work presents two cheap and fast diagnostic protocols. These protocols use latex obtained from fruits, leaves and stems, and are based on the extraction and visualization of nucleic acids. Presence of the virus is confirmed by the visualization of dsRNA on agarose (1\%) gel in $1 \mathrm{X}$ TBE. Using these protocols it is possible to confirm the presence of the virus in young and assymptomatic plants.
O mamão (Carica papaya L.) é uma fruta tropical de grande importância econômica, sendo o Brasil o principal produtor mundial. O cultivo do mamoeiro no Brasil apresentou um crescimento acentuado na década de 90, tendo contabilizado um aumento de 151\% na área colhida (de 16.012 ha em 1990 para 40.202 ha em 2000), e um acréscimo de $164 \%$ na quantidade produzida (de 642.581 em 1990 para 1.693.779 mil frutos em 2000). Em 2002 o mamão teve sua área colhida e quantidade produzida reduzidas para 35.626 ha e 1.597 .696 mil frutos, respectivamente. $\mathrm{O}$ valor da produção nacional de mamão em 2002 foi de aproximadamente 500 milhões de reais (IBGE, 2004). A produção de mamão no Brasil destinase principalmente para o mercado interno, porém, durante toda a década passada foi observado um crescimento contínuo no volume exportado. Este crescimento se deu principalmente após a abertura do mercado dos EUA a partir de 1998. No ano de 1990 o Brasil exportou 4.071 ton, o que rendeu U\$ 2.027.000,00. Já em 2001, foram exportadas 22.804

\footnotetext{
* Bolsista CNPq-RHAE
}

ton, rendendo U\$ 18.502.886,00; um aumento de 560\% no volume exportado e $872 \%$ no valor arrecadado (SECEXMDIC, 2002).

Apesar desta performance bastante positiva na última década, a cultura do mamoeiro sofre diversos problemas fitossanitários. No Brasil, as viroses constituem o principal grupo de patógenos que causam doenças em mamão, podendo infetar até $100 \%$ da lavoura em poucos meses, caso nenhuma forma de controle seja utilizada. Em todo o mundo, já foram relatadas aproximadamente dez espécies de vírus atacando esta cultura (Lima et al., 2001), porém, no Brasil, até o momento, só foram descritos três: o vírus da mancha anelar do mamoeiro (Papaya ringspot virus, PRSV-P), causador da "Mancha Anelar" ou "Mosaico"; o vírus do amarelo letal do mamoeiro (Papaya lethal yellowing virus, PLYV), causador do "Amarelo Letal"; e o vírus da meleira do mamoeiro (Papaya meleira virus, $\mathrm{PMeV}$ ), causador da "Meleira". Das três espécies que ocorrem no Brasil, esta última é a menos conhecida devido à falta de estudos e ferramentas que possibilitem a sua classificação taxonômica, avaliação de espectro de hospedeiros, definição 
da gama de vetores, etc.

A meleira foi constatada pela primeira vez na década de 80 em plantações no extremo Sul da Bahia (Nakagawa et al., 1987; Correa et al., 1988) e rapidamente se disseminou pelas principais regiões produtoras do país: Norte do Espírito Santo, Extremo Sul da Bahia, Pernambuco, Paraíba e Ceará (Rodrigues et al., 1989b; Barbosa et al., 1997; Alves Júnior et al., 2001). O principal sintoma da meleira caracteriza-se por exsudação excessiva de látex de consistência mais fluido que o normal, dando aos frutos um aspecto enegrecido devido à oxidação do látex. Além disso, a consistência e o sabor dos frutos se alteram, tornando-os impróprios para a comercialização. Manchas claras na casca e na polpa dos frutos também são observadas. Em folhas jovens podem surgir regiões com necrose, principalmente nas margens das mesmas (Rodrigues et al., 1989; Rodrigues et al., 1989b; Rodrigues et al., 1989c).

Kitajima et al. (1993) apresentaram evidências de que o agente causal da meleira poderia ser um vírus, ao detectarem, em suspensão de látex extraído de frutos ou folhas de plantas com os sintomas, partículas isométricas de vírus medindo cerca de $50 \mathrm{~nm}$ de diâmetro, e ao purificarem um fragmento de dsRNA de cerca de $12 \mathrm{~kb}$ a partir de tecidos de plantas doentes. A comprovação da etiologia viral da meleira foi feita por MacielZambolim et al. (2000 e 2003), que pela primeira vez purificaram o vírus e confirmaram que uma molécula de dsRNA é o genoma viral.

Atualmente, poucos métodos de detecção do vírus da meleira estão descritos, sendo que estes se baseiam na observação de sintomas nos frutos e em extrações de dsRNA viral em coluna de CF11 a partir de tecidos vegetais. A diagnose somente mediante observação de sintomas nos frutos cria o inconveniente de se manter plantas infetadas no campo, servindo como fonte de inoculo, por um longo período. Já a extração de dsRNA em coluna de CF11 é um método laborioso e não passível de uso em larga escala (i.e.: dezenas de amostras/dia). Só recentemente foi proposto um método de detecção rápida que utiliza visualização de dsRNA viral a partir da aplicação, diretamente em gel de agarose, de alíquotas de látex de mamoeiros infetados (Habibe \& Nascimento, 2002).

Neste trabalho apresentamos dois novos sistemas de diagnose precoce para essa enfermidade. Esses sistemas podem ser utilizados em larga escala (dezenas ou até centenas de amostras podem ser analisadas por dia), com resultados rápidos e custo relativamente baixo. Em ambos os protocolos, a presença do vírus é confirmada pela visualização do seu dsRNA em gel de agarose a $1 \%$.

O material utilizado foi látex extraído de frutos de mamoeiro apresentando os sintomas da meleira ou com suspeita de estarem infetados. Para se proceder ao diagnóstico, deve se utilizar látex diluído em $2 \mathrm{~V}$ de tampão citrato de amônio 0,1M (pH 6,5). Uma vez diluído em tampão citrato de amônio, a amostra pode ser mantida por dias à temperatura ambiente. Para as análises, foram utilizadas amostras que, em algumas situações, ficaram uma semana em trânsito, não afetando os resultados dos experimentos.

\section{Protocolo 1}

No primeiro método de diagnose desenvolvido, adicionou-se $1 \mathrm{~V}$ de tampão de extração (Tris $0,2 \mathrm{M}, \mathrm{NaCl}$ 0,3 M, EDTA 25 mM e SDS $2 \%$, pH 7,5) a $350 \mu l$ do látex diluído em citrato de amônio $0,1 \mathrm{M}$ (pH 6,5) e $14 \mu \mathrm{l}$ proteinase K $(20 \mathrm{mg} /$ $\mathrm{ml}$ ). Incubou-se a $37^{\circ} \mathrm{C}$ por $30 \mathrm{~min}$. Em seguida, procedeu-se a uma primeira extração com $1 \mathrm{~V}$ de fenol saturado com Tris-HCl (pH 7,5), e uma segunda extração com $1 \mathrm{~V}$ de clorofórmio/ álcool isoamil (24:1). A centrifugação para as duas extrações foi de $8000 \mathrm{rpm}$ por 4 min à temperatura ambiente. Aos $400 \mu \mathrm{l}$ da fase aquosa, foram adicionados $0,1 \mathrm{~V}$ de acetato de sódio $3 \mathrm{M}(\mathrm{pH} 5,2)$ e $2,5 \mathrm{~V}$ de etanol absoluto gelado $\left(-20^{\circ} \mathrm{C}\right)$, incubando no congelador ou freezer por $20 \mathrm{~min}$. Em seguida, centrifugou-se as amostras a $12000 \mathrm{rpm}$ por $20 \mathrm{~min}$ à temperatura ambiente, descartando-se o sobrenadante. O precipitado permaneceu repousado por $15 \mathrm{~min}$ ao ar livre para secar e depois foi ressuspendido com 20-50 $\mu$ le água destilada ou TE (Tris $10 \mathrm{mM}$ e EDTA $1 \mathrm{mM}, \mathrm{pH}$ 7,5). As amostras foram quantificadas em espectrofotômetro para padronizar a concentração das mesmas. Em seguida, 500 ng das amostras foram submetidas a eletroforese em gel de agarose 1\%, em TBE 1X, a $4 \mathrm{~V} / \mathrm{cm}$. Com o objetivo de encurtar o tempo de processamento do material, pode-se aplicar no gel de agarose uma alíquota de $10 \mu \mathrm{l}$ da amostra sem quantificação prévia. Uma amostra de látex é processada, até o resultado final, em torno de $3 \mathrm{~h}$.

\section{Protocolo 2}

No segundo método de diagnóstico desenvolvido, 500 $\mu \mathrm{l}$ de látex diluído em tampão citrato de amônio foram fervidos por $30 \mathrm{~s}$ para romper as partículas virais. Em seguida, foi adicionado $1 \mathrm{~V}$ de fenol saturado com Tris- $\mathrm{HCl}(\mathrm{pH} 7,5)$, agitando-se vigorosamente por alguns segundos. Procedeuse à centrifugação a $8000 \mathrm{rpm}$ por 4 min a temperatura ambiente para separar a fase fenólica da aquosa. Finalmente, $20 \mu \mathrm{l}$ da fase aquosa foram submetidos à eletroforese em gel de agarose $1 \%$, em TBE $1 \mathrm{X}$, a $4 \mathrm{~V} / \mathrm{cm}$ durante $1 \mathrm{~h}$. O resultado demostrou que $30 \mathrm{~s}$ de fervura foram suficientes para romper as partículas virais sem degradar o dsRNA. Tempos maiores desnaturam o dsRNA, tornando-o quase imperceptível no gel. Este procedimento leva em torno de uma $1 \mathrm{~h}$ e 20 min para ser finalizada.

Os métodos desenvolvidos neste trabalho levaram em consideração a presença das partículas virais no látex (Kitajima et al., 1993; Maciel-Zambolim et al., 2003), principalmente dos frutos. Normalmente quatro bandas de ácidos nucléicos têm sido observadas ao utilizar o protocolo 1 em plantas infetadas, enquanto que só uma banda tem sido observada em plantas sadias (Figura 1A). A natureza dessas bandas foi determinada mediante digestão diferencial com DNase I e RNase A, sendo que a banda de maior tamanho, e que também foi observada nas plantas sadias era DNA, enquanto que as demais eram RNA (Figura 1B). Entre essas bandas de RNA ocorre uma, de aproximadamente $12 \mathrm{~kb}$, que co-migra com a banda de dsRNA extraída a partir da partícula viral purificada (dados não mostrados). Para verificar se o 

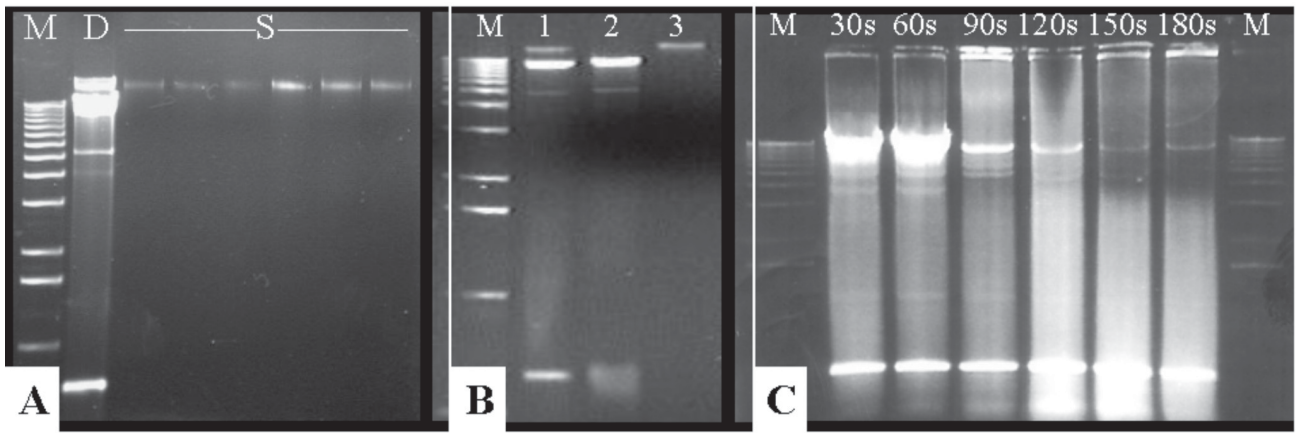

FIG. 1 - A) Ácidos nucléicos extraídos a partir de látex de frutos de mamoeiro (Carica papaya) utilizando o método da proteinase K (D, látex de planta infetada; S, látex de planta sadia); B) Ácidos nucléicos extraídos a partir de látex de planta doente mostrando a natureza das bandas (1, látex sem tratamento; 2, tratamento com DNase I; 3, tratamento com RNase A); C) Extração de ácidos nucléicos utilizando a fervura do látex de planta infetada em diferentes tempos de incubação em segundos (s). M - 1 kb DNA Ladder.

mesmo resultado seria obtido tratando látex de outras partes da planta, o mesmo procedimento foi feito com amostras de látex extraídas das folhas e raízes e dos caules e pecíolos de plantas com sintomas da meleira. Sendo possível neles detectar o dsRNA viral (dados não mostrados).

Sessenta e cinco amostras de látex de frutos de mamoeiros infetados e sadios, 50 oriundas do Espírito Santo e 15 da Paraíba/Pernambuco (estas últimas fornecidas pelo Prof. Gilvan Pio Ribeiro da UFRPe), foram submetidas ao teste de diagnóstico utilizando o protocolo 1 (Figuras 2A e 2B - só são apresentados os resultados de 40 amostras). As amostras quando recebidas não estavam rotuladas como sadias ou infetadas para não induzirem a interpretação dos resultados. O uso do protocolo 1 levou a 100\% de acerto no diagnóstico. Algumas poucas amostras, coletadas no Espírito Santo, e tidas como sadias pelos fornecedores por terem sido coletadas de plantas assintomáticas, foram classificadas como infetadas pelo teste. A confirmação de que estas estavam infetadas quando da coleta do látex foi feita mais tarde com o aparecimento dos sintomas da meleira nas plantas.

O uso em larga escala desses sistemas de diagnóstico depende da capacidade do laboratório, principalmente no que se refere à disponibilidade de micro-centrífugas e de cubas de eletroforese horizontal. No nosso laboratório uma única pessoa pode analisar com facilidade pelo menos 50 amostras/ dia, utilizando o protocolo 1 . Com vistas a simplificar ainda mais este protocolo, foram feitas alterações que resultaram no protocolo 2. Este segundo protocolo, baseado na fervura do látex, mostrou necessitar de somente $30 \mathrm{~s}$ de fervura (Figura 1C). Este protocolo permite o manuseio do dobro de amostras, i. e., 100 amostras/dia.

Estes novos sistemas de diagnóstico precoce, além de utilizar um volume pequeno de látex (350-500 $\mu \mathrm{l}$ ), mostraram-se relativamente baratos, rápidos, confiáveis e podem ser utilizados na análise de um grande número de amostras por dia, além de detectar o vírus em plantas infetadas ainda jovens ou assintomáticas.
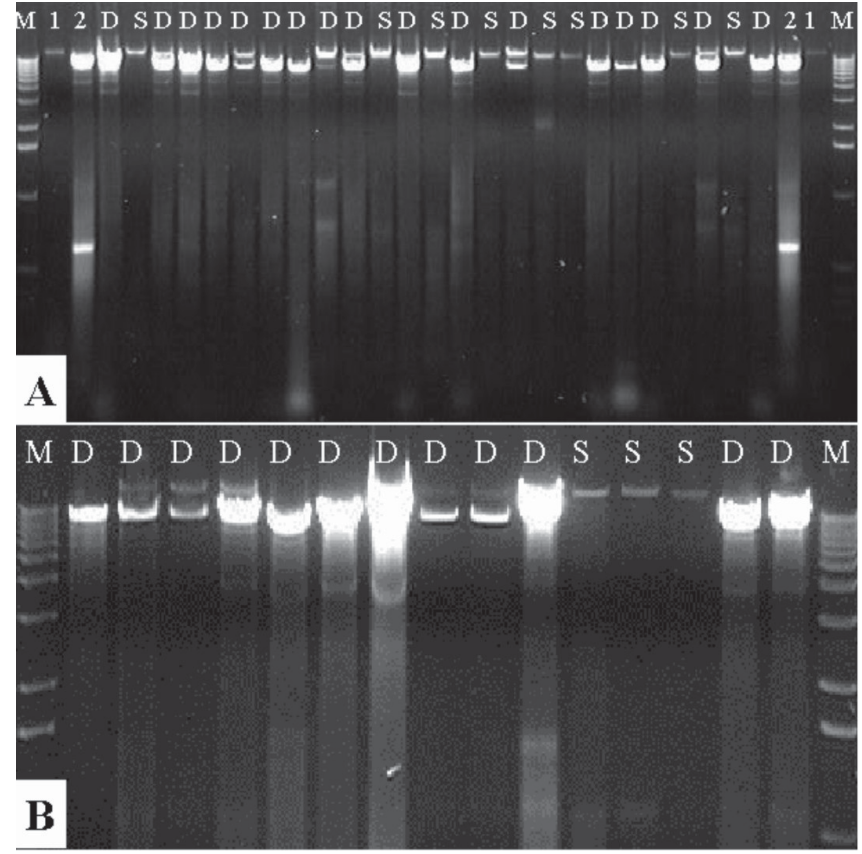

FIG. 2 - Extração de ácidos nucléicos a partir de látex de frutos de mamoeiros (Carica papaya) infetados (D) e sadios (S). As plantas diagnosticadas como infetadas possuem uma banda de tamanho correspondente ao do dsRNA viral, $12 \mathrm{~kb}$, e as plantas sadias possuem somente uma banda de alto peso molecular correspondente ao DNA total de mamão. A) Amostras de látex do Espírito Santo (1, látexcontrole de planta sadia; 2, látex-controle de planta infetada); B) Amostras de látex de Pernambuco/Paraíba. M - 1 kb DNA Ladder.

\section{REFERÊNCIAS BIBLIOGRÁFICAS}

ALVES JÚNIOR, M., SOUZA JUNIOR, M.T., RIBEIRO, G. P., ANDRADE, G.P. \& SILVA, J.L. Ocorrência simultânea de meleira e mancha anelar em mamoeiros no estado da Paraíba. In: XXXIV Congresso Brasileiro de Fitopatologia, 2001, São Pedro, SP. Fitopatologia Brasileira 26:512. 2001.

BARBOSA, C.J., PATROCÍNIO, E., HABIBE, T.C., NASCIMENTO, A.S. \& MATRANGO, W.J.R. Detecção de formas 


\section{E.R. Tavares et al.}

replicativas de vírus em plantas de mamoeiro inoculadas com látex de plantas afetadas pela meleira. Biotemas 13: 47-53. 2000.

CORREA, F.J.F., FRANCO, B.J.D.C., WATANABE, H.S., SAKAY, M.Y. \& YAMASHITA, E.M.A. Estudo preliminar sobre exsudação do látex do mamoeiro - Teixeira de Freitas. Anais, 20 o Simpósio Brasileiro sobre a Cultura do Mamoeiro, Jaboticabal, SP. 1988. pp.409-428.

HABIBE, T. C. \& NASCIMENTO, A. S. Diagnose precoce da meleira do mamoeiro. Embrapa Mandioca e Fruticultura - Comunicado Técnico 77. 2002.

IBGE - SIDRA (Instituto Brasileiro de Geografia e Estatística Sistema IBGE de Recuperação Automática). Disponível em: http:// www.sidra.ibge.gov.br/bda/ Acesso em 2004.

KITAJIMA, E.W., RODRIGUES, C., SILVEIRA, J., ALVES, F., VENTURA, J.A., ARAGÃO, F.J.L. \& OLIVEIRA, L.H.R. Association of isometric virus-like particles, restricted to laticifers, with meleira (sticky disease) of papaya (Carica papaya). Fitopatologia Brasileira 18:118-122. 1993.

LIMA, R.C.A., LIMA, J.A.A., SOUZA JR., M.T., PIO-RIBEIRO, G. \& ANDRADE, G.P. Etiologia e estratégias de controle de viroses do mamoeiro no Brasil. Fitopatologia Brasileira 26:689702. 2001.

MACIEL-ZAMBOLIM, E., BARROS, D.R., MATSUOKA, K., KUNEIDA, S., CARVALHO, M.G. \& ZERBINI, F.M. Purification and partial characterization of papaya meleira. virus. Fitopatologia Brasileira 33:442. 2000. (Resumo).

MACIEL-ZAMBOLIM, E., KUNIEDA, S., MATSUOKA, K., CARVALHO, M.G. \& ZERBINI, F.M. Purification and some properties of Papaya meleira virus, a novel virus infecting papayas in Brazil. Plant Pathology 52:389-394. 2003.

NAKAGAWA, J., TAKAYAMA, Y. \& SUZUKAMA, Y. Exsudação de látex pelo mamoeiro. Estudo de Ocorrência em Teixeira de Freitas, BA. Anais, $9^{\circ}$ Congresso Brasileiro de Fruticultura, Campinas, SP. 1987. pp.555-559.

RODRIGUES, C.H., ALVES, F.L., MARIN, S.L.D. Ocorrência e sintomas de meleira do mamoeiro (Carica papaya) no estado do Espírito Santo. Fitopatologia Brasileira 14:118. 1989a.

RODRIGUES, C.H., ALVES, F.L., MARIN, S.L.D., MAFFIA, L.A., VENTURA, J.A. \& GUTIERREZ, A.S.D. Meleira do mamoeiro no estado do Espírito Santo: enfoque fitopatológico. Linhares: EMCAPA, In: Selecta de Trabalhos sobre a Meleira do Mamoeiro. 1989b.

RODRIGUES, C.H., VENTURA, J.A. \& MAFFIA, L.D. Distribuição e transmissão da meleira em pomares de mamão no Espírito Santo. Fitopatologia Brasileira 14:118. 1989c.

SECEX (Secretaria do Comércio Exterior)/ MDIC (Ministério do Desenvolvimento Indústria e Comércio). Disponível em:http// :www.mdic.gov.br/Micn001.htm . Acesso em 2002. 